\title{
On the Occurrence of the Linyphiid Spider Neriene clathrata (Sundevall, 1830) in Turkey (Araneae, Linyphiidae)
}

\author{
Rahşen S. KAYA ${ }^{1 *}$, Gökhan GÜNDÜZ1 ${ }^{1}$ H. Burcu ERGENE¹, Ersen Aydın YAĞMUR² \\ ${ }^{1}$ Uludă̆ University, Faculty of Arts and Sciences, Department of Biology, TR-16059 Nilüfer, Bursa, Turkey \\ ${ }_{2}^{2}$ Celal Bayar University, Alaşehir Vocational School, TR-45600 Alaşehir, Manisa, Turkey \\ ORCID ID: Rahşen S. KAYA: https:/ / orcid.org/0000-0002-3769-9105; Gökhan GÜNDÜZ: https://orcid.org/0000-0001-8957-3267 ; H. Burcu \\ ERGENE: https://orcid.org/0000-0001-7494-3261; Ersen Aydın YAĞMUR: https://orcid.org/0000-0002-0396-3975
}

\begin{abstract}
Received: 04.02 .2019
Accepted: 13.06 .2019

Published online: 30.06 .2019

Issue published: 30.06 .2019

Abstract: The linyphiid spider Neriene clathrata (Sundevall, 1830) was collected several times from Turkey, but the species is still unlisted in the latest checklists. Here we briefly summarize the information on this species with newly collected samples. A morphological diagnosis and comparative illustrations are provided for N. furtiva (O. Pickard-Cambridge, 1871) and N. radiata (Walckenaer, 1841) as well.

Keywords: Neriene furtiva, Neriene radiata, distribution, Anatolia

\section{Neriene clathrata (Sundevall, 1830) Örümcek Türünün Türkiye'deki Durumu (Araneae, Linyphiidae)}

Öz: Linyphiidae üyesi örümcek türü Neriene clathrata (Sundevall, 1830) Türkiye'den birkaç kez toplanmış, ancak bu tür güncel tür kontrol listelerinde hala listelenmemektedir. Bu çalışmada, tür hakkındaki bilgiler yeni toplanan örneklerle kısaca özetlenmiştir. Ayrıca, N. furtiva (O. Pickard-Cambridge, 1871) ve N. radiata (Walckenaer, 1841) türleri için karşılaştırma şekilleri ve morfolojik tanıları sunulmuştur.
\end{abstract}

Anahtar kelimeler: Neriene furtiva, Neriene radiata, yayılış, Anadolu.

\section{Introduction}

The Linyphiidae Blackwall, 1859 is one of the most diverse families of spiders, with 4573 species in 611 genera. Neriene Blackwall, 1833 is a large linyphiid genus which contains 60 species and has a wide distribution mostly in the Far East (World Spider Catalog, 2019).

The genus Neriene was established by Blackwall in 1833. The first described species of the genus was $N$. marginata Blackwall, 1833. Although the first species was described, the author did not specify the type species of the genus (Blackwall, 1833). The type species designation was carried out by Bonnet (1958). Thorell (1870) designated the N. marginata as the synonym of Linyphia clathrata Sundevall, 1830. The author also suggested that the type species should be included in the same genus as the $L$. triangularis (Clerck, 1757) and; therefore, he considered the genus Neriene to be a synonymy of Linyphia Latreille, 1804 (Thorell, 1870). This situation is generally accepted, except for some American authors in the early 1900s. They used the generic name Neriene for some Central American and Nearctic species. Then, van Helsdingen re-evaluated Linyphia genus in his extensive study in 1969 and removed the synonymy. Moreover, van Helsdingen described five species groups of the genus Neriene. Today, this approach is generally accepted (van Helsdingen, 1969; World Spider Catalog, 2019).

Seven species of Neriene are distributed in the west Palaearctic (Europe, Mediterranean, Iran and North Africa). These are: N. clathrata, N. emphana (Walckenaer,
1841), N. furtiva (O. Pickard Cambridge, 1871), N. hammeni (van Helsdingen, 1963), N. montana (Clerck, 1757), N. peltata (Wider, 1834) and N. radiata (Walckenaer, 1841). Three of them are found in Iran, five in Caucasus, two in North Africa, and six in Bulgaria (World Spider Catalog, 2019). The first report of the genus in Turkey was recorded by Nosek (1905) who examined some spiders that were collected from different parts of Turkey by Dr. A. Penther in 1902. Unknown number of female individuals from this collection was considered as Linyphia furtiva (=Neriene furtiva) from islands of the Marmara Sea by Nosek (1905). The same species was included in the preliminary checklist of spiders of Turkey prepared by Karol (1967). van Helsdingen (1969) revised the genus Linyphia and four female specimens collected from two provinces of Northern Region of Turkey were also examined. One of these specimens was considered as $N$. radiata; but the remaining three specimens were considered as $N$. peltata (van Helsdingen, 1969). In some later publications these two species were re-reported (Karabulut \& Türkeş, 2011; Danışman \& Coşar, 2013). Also, N. clathrata was studied by Sancak (2007) for his master's thesis and published later (Bayram, Sancak, Danışman, \& Çorak, 2007). However, there is no information about this record in the checklist of spiders of Turkey (Danışman, Kunt, \& Özkütük, 2018). So, there are actually four species of Neriene recorded in Turkey.

The aim of the current paper is to add $N$. clathrata (Sundevall, 1830) to the list of linyphiid spider fauna of Turkey and to update the situation of the genus in Turkey. 
The additional comparative material of $N$. furtiva and $N$. radiata are presented. Also, diagnostic information is provided for these three species.

\section{Material and Methods}

Five females and one subadult specimens of N. clathrata were collected by hand aspirator from Düzce, Kırklareli, and İstanbul provinces in Turkey (Fig. 1).

Locality 1: Düzce Province: 2ㅇ, 07.11.2014, Dadalıköy village, leg. B. Badur.

Locality 2: Kirklareli Province: 2 우, 1subadult male, 02.04.2016, 41 ${ }^{\circ} 03^{\prime} 00^{\prime \prime} \mathrm{N}, 2^{\circ} 11^{\prime} 14 " \mathrm{E}, 574 \mathrm{~m}$. leg. H.B. Ergene.

Locality 3: İstanbul Province, Aydos: 1, 30.06.2016, $40^{\circ} 51^{\prime} 11 " N$, $29^{\circ} 14^{\prime} 49 "$ E, $874 m$. leg. R.S. Kaya, E.A. Yağmur, Y. Gürkan.

\section{Comparative material:}

$N$. furtiva: one female specimen was collected by hand aspirator from a stony area of Bursa province (Locality 4: Bursa Province, Karacabey, 1ㅇ, 06.05.2015, $40^{\circ} 14^{\prime} 91^{\prime \prime N}, 28^{\circ} 22^{\prime} 96^{\prime \prime E}, 20 \mathrm{~m}$. leg. R.S. Kaya).

$N$. radiata: Three females and one male specimens were collected by hand aspirator from Bursa province (Locality 5: Bursa Province, Uludağ Mountain, 1 우 and $1{ }^{\widehat{\gamma}}$ from Babasultan village, 20.06.2006; 2 우 from Cumalıkızık village, 12.04.2007, leg. R.S. Kaya).

The identification was made by using the descriptions of van Helsdingen (1969); Li, Liu, \& Chen (2018) and Nentwig, Blick, Gloor, Hanggi, \& Kropf (2018). The digital images and measurements were taken by Leica Apo 8 stereo microscope. The measurements are taken from the dorsal side of the body. All measurements are in millimeters $(\mathrm{mm})$. The specimens were preserved in the collection of the Zoological Museum, Department of Biology, Uludağ University, Bursa, Turkey.

The taxonomy follows World Spider Catalog (2019) and the terminology of male palpus follows van Helsdingen (1969) and Li et al. (2018).

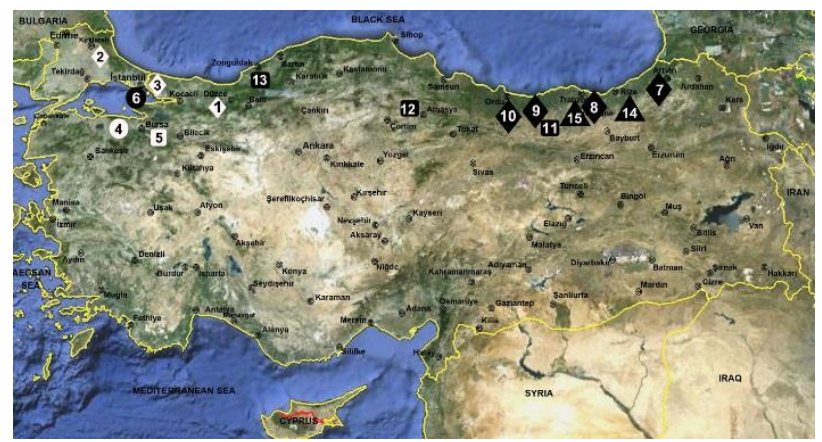

Figure 1: The localities for Neriene in Turkey. New localities are marked with white: $(N$. clathrata $(1,2,3), N$. furtiva (4), N. radiata (5)); and previous localities with black: $N$. clathrata $(7,8,9,10$ by Sancak 2007; Bayram et al., 2007), N. furtiva (6 by Nosek, 1905), N. radiata (11 by Danışman \& Coşar, 2013; Karabulut \& Türkeş, 2011 - 12 by van Helsdingen, 1969 - 13 by Karabulut \& Türkeş, 2011), N. peltata (14 by Karabulut \& Türkeş, 2011- 15 by van Helsdingen, 1969).

\section{Results}

Family Linyphiidae Blackwall,1859

\subsection{Species N. clathrata (Sundevall, 1830) (Figs. 2-3, 8-10)}

Female: Total length 3.7- $3.9 \mathrm{~mm}$. Prosoma dark yellowbrown. Abdomen ovoidal, with dorso-lateral dark bands and dorsal white blotches. Abdomen with several small light pairs of spots ventrally (Figs. 2-3). Distance between posterior median eyes greater than diameter of one of the posterior median eyes. Anterior median eyes smaller than the lateral ones. Chelicerae dark brown. Femur I shorter than prosoma. Legs light yellow-brown, long and slender. Femur I with two dorsal spines. Tibia I with one prolateral spine. Metatarsus IV without trichobothrium. Spinnerets dark. The epigyne is not protruding; atrium opening is semicircular and small in ventral view (Figs. 8-10).

Diagnosis: $N$. clathrata and $N$. furtiva are members of the clathrata species group of the genus Neriene. They can be easily distinguished from the other species by their abdominal patterns, coloration and genital structures. Abdominal pattern of $N$. clathrata with distinct white and dark dorsal bands and 2-3 pairs of small ventral white spots. N. clathrata differs from $N$. furtiva by having two dorsal spines on the femur I (one in N. furtiva). The epigyne of $N$. clathrata is not protruding and has a small atrium than in N. furtiva.

Distribution: North America, Europe, North Africa, Caucasus, Russia, Central Asia, China, Korea, Japan (World Spider Catalog, 2019).

In Turkey: Ordu, Trabzon, Rize, Artvin (Bayram et al., 2007); Düzce, Kırklareli, İstanbul (new localities, present study)

Material examined: Düzce Province: 2우, 07.11.2014, Dadalıköy village, leg. B. Badur; Kırklareli Province: 2 2 + , 1subadult male, 02.04.2016, $41^{\circ} 03^{\prime} 00^{\prime \prime} \mathrm{N}, 27^{\circ} 11^{\prime} 14 " \mathrm{E}, 574 \mathrm{~m}$. leg. H.B. Ergene; İstanbul Province, Aydos: 1ㅇ, 30.06.2016, $40^{\circ} 51^{\prime} 11^{\prime \prime N}, 29^{\circ} 14^{\prime} 49^{\prime \prime}$ E, 874m. leg. R.S. Kaya, E.A. Yağmur, Y. Gürkan.
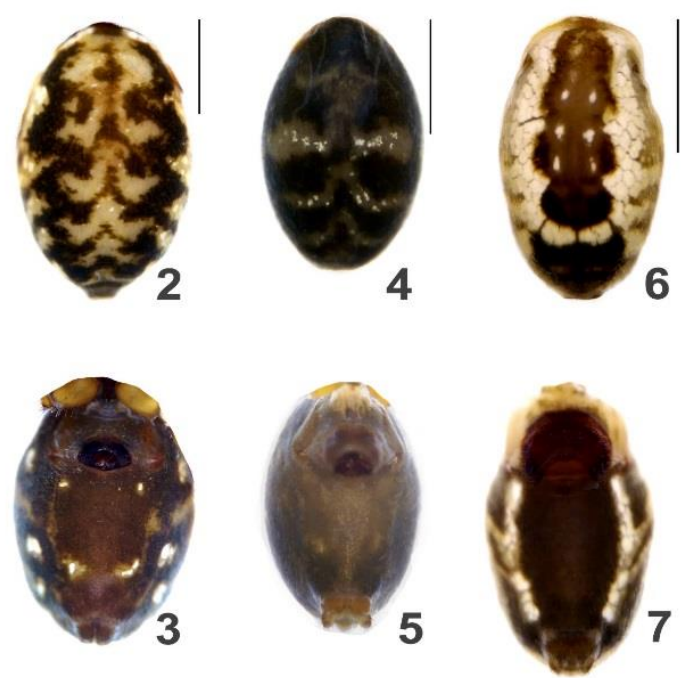

Figures 2-7: Female abdominal patterns and spots of three Neriene species. 2. N. clathrata, dorsal view. 3. N. clathrata, ventral view. 4 . N. furtiva, dorsal view. 5. N. furtiva, ventral view. 6. N. radiata, dorsal view. 7. N. radiata, ventral view. Scale lines: 2: $0.7 \mathrm{~mm}, 4$ : $0.8 \mathrm{~mm}, 6: 1 \mathrm{~mm}$. 

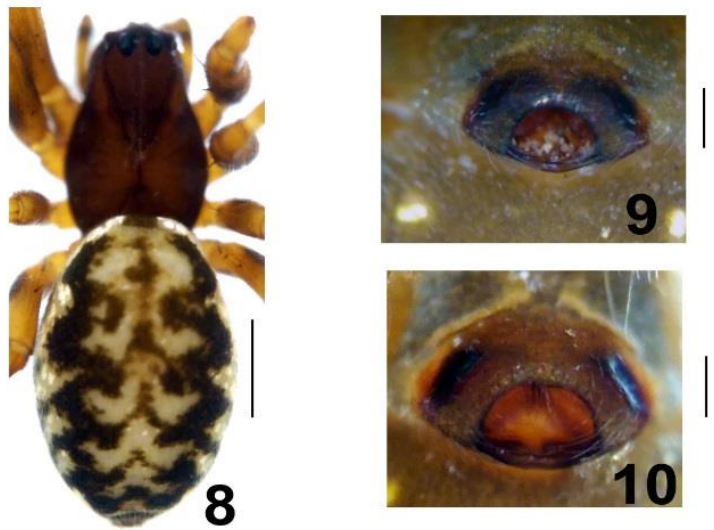

Figures 8-10: Neriene clathrata (Sundevall, 1830). 8. Female general habitus, dorsal view. 9-10. epigyne, ventral view. Scale lines: 8: $0.7 \mathrm{~mm}$, 9-10: $0.1 \mathrm{~mm}$.

3.2. Species N. furtiva (O. Pickard-Cambridge, 1871) (Figs. $4-5,11-12$ )

Female: Total length $3.9 \mathrm{~mm}$. Prosoma dark brown. Abdomen ovoid, with gray and white pair of lines and spots on black background. Abdomen with a few white spots ventrally (Figs. 4-5). Distance between posterior median eyes greater than diameter of one of the posterior median eyes. Anterior median eyes smaller than the lateral ones. Chelicerae dark brown, lighter at base. Femur I equal in length with prosoma. Legs long and slender. Femur I with one dorsal spine. Tibia I with one prolateral spine. Metatarsus IV without trichobothrium. Spinnerets dark and without any pattern on its surrounding. The epigyne is protruding and atrium opening is wide (Figs. 11-12).

Diagnosis: Dorsal surface of abdomen with some white fine lines. Ventral surface of abdomen is brownish black and without any light spots. N. furtiva differs from $N$. clathrata by having one dorsal spine on femur I. Also the epigynum of $N$. furtiva more protruding than in $N$. clathrata.

Distribution: Europe, North Africa, Russia (World Spider Catalog, 2019).

In Turkey: İstanbul, Büyükada Island (Nosek, 1905), Bursa (new locality, present study)

Material examined: Bursa Province, Karacabey, 19, 06.05.2015, 40¹4'91"N, 28²2'96"E, 20 m. leg. R.S. Kaya.
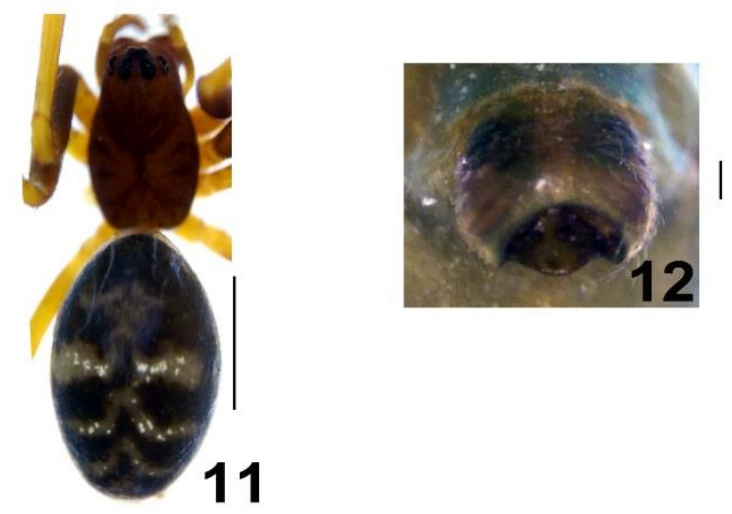

Figures 11-12: N. furtiva (O. Pickard-Cambridge, 1871). 11. Female general habitus, dorsal view. 12. epigynum, ventral view. Scale lines: 11: $1 \mathrm{~mm}, 12: 0.1 \mathrm{~mm}$.

\subsection{Species N. radiata (Walckenaer, 1841) (Figs. 6-7, 13-17)}

Male: Total length $4.0 \mathrm{~mm}$. Prosoma medially dark brown, slightly lighter laterally. Abdomen cylindrical, with two narrow white lines laterally on dark background (Fig. 15). Posterior eye row straight. Distance between posterior median eyes equal to diameter of one of the posterior median eyes. Anterior median eyes smaller than the lateral ones. Chelicerae dark brown, lighter at base. Femur I longer than prosoma. Legs long and slender. Femora without spines. Tibia I with one prolateral spine. Metatarsus IV without trichobothrium. Spinnerets dark. Paracymbium with long, slender and apically tapering distal arm. Terminal apophysis long and grooved. Median apophysis slightly curved and apically bifurcated; dorsal arm broader than ventral arm (Figs. 16-17).

Female: Total length 3.8-5.1 mm. Prosoma brown, slightly lighter laterally. Abdomen ovoidal, with two narrow white lines radiating on posterior half laterally. Abdomen with two white longitudinal lines ventrally (Fig. 13). Posterior eye row straight. Distance between posterior median eyes equal to diameter of one of the posterior median eyes. Anterior median eyes smaller than the lateral ones. Chelicerae dark brown. Femur I longer than prosoma. Legs long and slender. Femora without spines. Tibia I with one prolateral spine. Metatarsus IV without trichobothrium. The entrance of epigyne wider than long. Scapus large and tapering forwardly (Fig. 14).

Diagnosis: This species could be distinguished from its congeners by having following characteristics: Abdomen with fine ventrolateral white lines. Posterior median eyes with tiny black rings. The distance between posterior median eyes smaller than the one between posterior lateral eyes. Dorsal spine on tibia I located lower than 0.10. Abdominal median dorsal band is broad.

Distribution: North America, Europe, Turkey, Caucasus, Russia, Kazakhstan, China, Korea, Japan (World Spider Catalog, 2019).

In Turkey: Zonguldak (Karabulut \& Türkeş, 2011), Giresun (Karabulut \& Türkeş, 2011; Danışman \& Coşar, 2013), Bursa (new locality, present study)

Material examined: Bursa Province, Uludağ Mountain, 19 and 1 $\widehat{\jmath}$ from Babasultan village, 20.06.2006; 2 우 from Cumalıkızık village, 12.04.2007, leg. R.S. Kaya

\section{Discussion}

Until now, four Neriene species have been reported from Turkey: N. clathrata, N. furtiva, N. radiata and N. peltata. Although N. clathrata was collected by Sancak (2007), the species is still not included in the updated checklists of spiders of Turkey. Here we presented the brief diagnosis, comparative pictures of genitalia and somatic characteristics of N. clathrata, N. furtiva and N. radiata based on newly collected specimens. All three species have widespread distribution pattern in the world.

There are seven species of the genus Neriene known from European countries now. Some of these species, such as N. emphana (Walckenaer, 1841) and N. montana (Clerck, 1757) have wide distribution in the Palaearctic (World Spider Catalog, 2019). According to this, these two species are most likely inhabiting in Turkey too and will may be found in the next studies. 


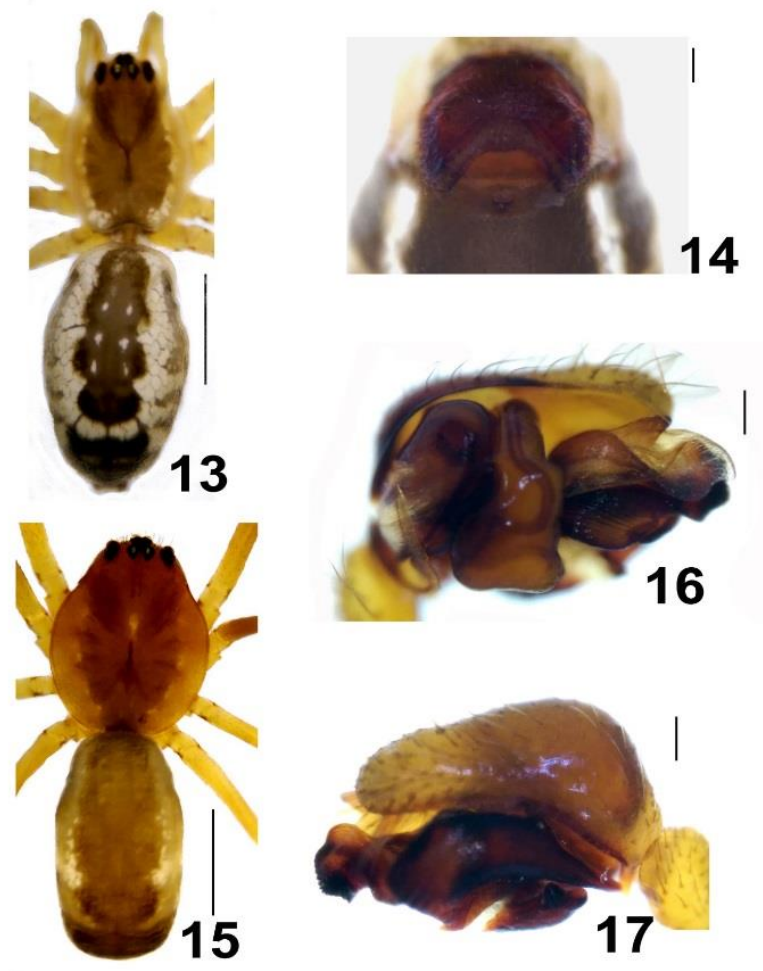

Figures 13-17: N. radiata (Walckenaer, 1841). 13. Female general habitus, dorsal view. 14. epigynum, ventral view. 15. Male general habitus, dorsal view. 16-17. Male right palpus. 16. retrolateral view. 17. Prolateral view. Scale lines: 13, 15: $1 \mathrm{~mm}$; 14, 16-17: 0.1 $\mathrm{mm}$.

\section{References}

Bayram, A., Sancak, Z., Danışman, T., \& Çorak, İ. (2007). Spider Fauna of the Argyopiformia Group of the North-East Blacksea Region (Superfamily: Argyopiformia, Araneae). Journal of Applied Biological Sciences, 1(2), 13-17.

Blackwall, J. (1833). Characters of some undescribed genera and species of Araneidae. London and Edinburgh Philosophical Magazine and Journal of Science, (3)3, 104-112, 187-197, 344-352, 436-443.

Bonnet, P. (1958). Bibliographia araneorum. Douladoure, Toulouse, 2(4), 3027-4230.

Danışman, T., \& Coşar, İ. (2013). A contribution to the knowledge of the linyphiid spider fauna of Turkey (Araneae: Linyphiidae). Acta Zoologica Bulgarica, 65(4), 567-570.

Danışman, T., Kunt, K.B., \& Özkütük, R.S. (2019). The Checklist of the Spiders of Turkey. Retrieved from http://www.spidersofturkey.info

Helsdingen, P.J. van (1969). A reclassification of the species of Linyphia Latreille based on the functioning of the genitalia (Araneida, Linyphiidae), I. Zoologische Verhandelingen Leiden, 105, 1-303.

Karabulut, H., \& Türkeş, T. (2011). New records of Linyphiidae (Araneae) for Turkish araneo-fauna. Serket, 12, 117-123.

Karol, S. (1967). Türkiye Örümcekleri I. Ön Liste. Ankara, Türkiye, Ankara Üniversitesi Basımevi., $37 \mathrm{pp}$.

Li, J.Y., Liu, J. \& Chen, J.A. (2018). A review of some Neriene spiders (Araneae, Linyphiidae) from China. Zootaxa, 4513(1), 1-90.

Nentwig, W., Blick, T., Gloor, D., Hänggi, A., \& Kropf, C. (2018). Araneae: Spiders of Europa. Retrieved from https://www.araneae.nmbe.ch

Nosek, A. (1905). Araneiden, Opilionen und Chernetiden. In Penther, A. \& E. Zederbauer (Eds.) Ergebnisse einer naturwissenschaftlichen Reise zum Erdschias-Dagh (Kleinasien), Annalen des Kaiserlich-Königlichen Naturhistorischen Hofmuseums in Wien, 20, 114-154.

Sancak, Z. (2007). Doğu Karadeniz bölgesi örümceklerinin (Araneae) sistematik ve faunistik açıdan incelenmesi (Yüksek Lisans Tezi), Kastamonu Üniversitesi, Kastamonu, Türkiye.

Thorell, T. (1870). Remarks on synonyms of European spiders. Part I. C.J. Lundström, Uppsala, Sweden, 96 pp.

World Spider Catalog (2019). Natural History Museum Bern. Retrieved from http:/ / wsc.nmbe.ch. doi: 10.24436/2. 